\title{
15. MIDDLE AND LATE EOCENE LARGER FORAMINIFERS FROM SITE 841 (TONGAN PLATFORM) ${ }^{1}$
}

\author{
George C.H. Chaproniere ${ }^{2}$
}

\begin{abstract}
Larger foraminifers were recovered from three levels within Hole 841B, located on the Tongan Platform. The lowest faunas are from Eocene beds (Unit V) in fault contact with an older rhyolitic volcanic sequence. These Eocene faunas are typified by two assemblages: one with Amphistegina waiareka, Asterocyclina matanzensis, Discocyclina omphala, Operculina pacifica, together with rare Heterostegina saipanensis and Sherbornina carteri; the second assemblage contains these species and, in addition, Spiroclypeus vermicularis. The lowest assemblage is associated with a middle Eocene planktonic foraminifer fauna (Acarinina, Morozovella), and the upper faunas with a late Eocene assemblage. This Eocene unit is disconformably overlain by a middle Miocene sequence (Unit IV) containing assemblages dominated by planktonic foraminifers. Two samples were found to contain shallow-water benthic foraminifers: one contained Amphistegina radiata, Cycloclypeus sp., Lepidocyclina (Nephrolepidina) ?howchini, and Sphaerogypsina globula; a second sample from this section contained only Amphistegina radiata. The third level at which larger foraminifers were found was in the lower part of the late Miocene section (Unit III), where late Eocene larger foraminifers (Asterocyclina matanzensis, Discocyclina omphala, Nummulites pengaronensis, and Pellatispira madaraszi) are present in a conglomeratic sequence with late Miocene planktonic foraminifers present in the matrix.

The two larger foraminifer assemblages of Unit $\mathrm{V}$ are typical of the $\mathrm{T} a_{3}$ and $\mathrm{T} b$ Letter Stages, which are distinguished by the presence of Spiroclypeus vermicularis. The T $a_{3}$ Letter Stage assemblage is associated with a Zone P14 planktonic fauna, and the $\mathrm{T} b$ Letter Stage assemblage with Zones P15 to P16 fauna.

The larger foraminifers associated with middle and late Eocene planktonic foraminifers are almost certainly in situ, and indicate water depths from between 50 and $100 \mathrm{~m}$ in the middle Eocene, shallowing to $<50 \mathrm{~m}$, and then gradually deepening to $>100 \mathrm{~m}$ by the end of the Eocene. The middle Miocene faunas have been derived from shallow-water environments adjacent to the sites of deposition (which would have been in excess of $100 \mathrm{~m}$ ), and may have been contemporaneous or reworked from rocks no older than the $\mathrm{T}_{5}$ Letter Stage. Late Eocene larger foraminifers ( $\mathrm{T} b$ Letter Stage) were reworked into the deep-water, late Miocene environments as products of erosion from adjacent exposures of Eocene carbonates.

A hiatus is probably present in the lower part of the Eocene section, separating the middle and late Eocene ( $\mathrm{T} a_{3}$ and $\mathrm{T} b$ Letter Stages-Zones P14 and P15). This is probably the result of eustatic changes. Unit V almost certainly contains the Eocene/Oligocene boundary, based on the planktonic foraminifer evidence, but larger foraminifers disappear some distance below this boundary, within Zones P15 or P16.

The larger foraminifer faunas from Units III and V provide evidence that water depths at this part of the Tongan Platform have increased from approximately $50 \mathrm{~m}$ during the late middle Eocene to below the calcium carbonate compensation depth by the late Miocene, respectively.
\end{abstract}

\section{INTRODUCTION}

Site 841 was located in $4810 \mathrm{~m}$ water depth on the eastern edge of the Tongan Platform adjacent to the Tongan Trench (Fig. 1). Lithologies of the lowest marine beds, Unit V, are calcareous volcanic muddy sandstones. At the base, these beds are in fault contact with rhyolitic sands (Parson, Hawkins, Allan, et al., 1992). Unit V ranges from Zones P15 (middle Eocene) to P18 (early Oligocene), based on planktonic foraminifers (Nishi and Chaproniere, this volume) and nannofossils (Quinterno, this volume). Few larger foraminifers occur in the lowest beds (Plate 1, Figs. 1-4), but they gradually become numerous, becoming most abundant in a thin, well-cemented, muddy volcanic sandstone (Plate 1, Figs. 3-4), and then gradually decreasing (Plate 2, Figs. 1-4) until they disappear within the middle part of the sequence. The planktonic foraminifer distribution is the inverse of that of the larger foraminifers. In thin section, all samples studied were packstones to wackestones.

Unit V is disconformably overlain by another sequence of volcanic sandstones and siltstones, Unit IV; these beds contain planktonic foraminifer assemblages from Zones N8 and N9 (Chaproniere and Nishi, this volume). Larger benthic foraminifers were found in two

\footnotetext{
${ }^{1}$ Hawkins, J., Parson, L., Allan, J., et al., 1994. Proc. ODP, Sci. Results, 135: College Station, TX (Ocean Drilling Program).

${ }^{2}$ Marine Geoscience Program, Australian Geological Survey Organisation, P.O. Box 378, Canberra, A.C.T. 2601, Australia.
}

samples from the lower part of this sequence; however, because of their fragmentation and the dominance of planktonic assemblages, they are clearly reworked into deeper waters.

The upper part of Unit IV is faulted against the overlying Unit III, a sequence of volcanic sandstones and conglomerates (Parson, Hawkins, Allan, et al., 1992). These overlying beds are mainly barren of foraminifers and, at best, contain very low-diversity assemblages. Nevertheless, the few assemblages recovered (Chaproniere and Nishi, this volume) indicate that these beds are Zone $\mathrm{N} 16$ or younger. A thin section of a sample from within a volcanic conglomerate (135-841B20R-3, 66-69 cm) contains Pulleniatina sp. (Plate 5, Fig. 1), and Globorotalia (Globorotalia) tumida ?plesiotumida (Plate 5, Fig. 2), indicating Zone N17B or younger. Specimens of larger foraminifers are found within the volcanic conglomerates, both as discrete fragmentary specimens or within lithoclasts. The poor preservation and low-diversity planktonic foraminifer assemblages and numerous barren intervals within Unit III suggest water depths close to or below the calcium carbonate dissolution (CCD) depth.

Identification of larger foraminiferids to generic level is normally adequate for biostratigraphic determination. Identification to this taxonomic level is readily achieved using either random or oriented thin sections. In general, identification at species level is enhanced using oriented sections; however, if sufficient material is available for the study of a number of specimens, then species identification can be made with a fair degree of confidence from random thin sections. For this study, the identification of some smaller benthic foraminifers 


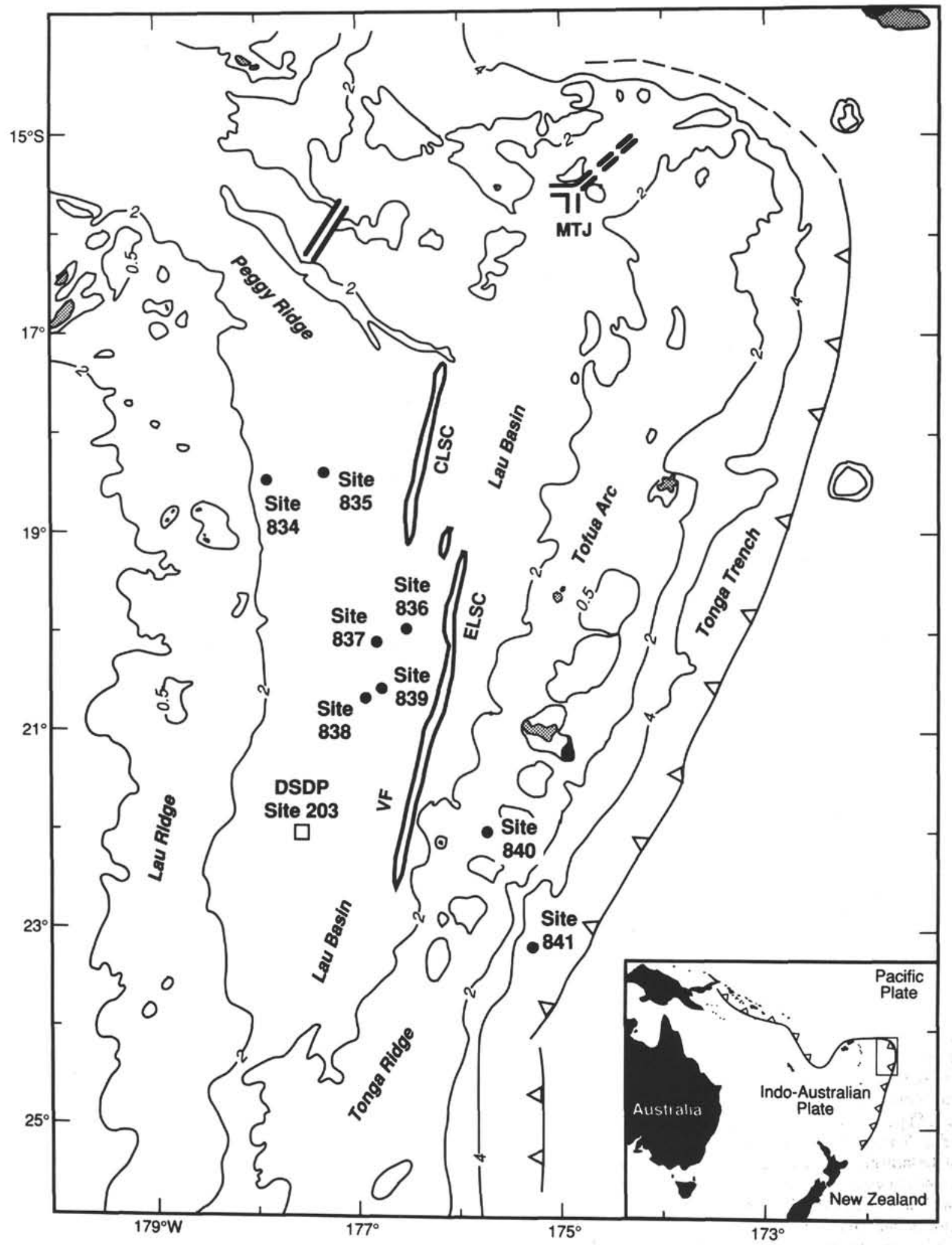

Figure 1. Map illustrating bathymetry and location of Site 841 (after Hawkins, Parson, Allan, et al., 1992). Islands include A = 'Ata, $\mathrm{E}=$ 'Eua, $\mathrm{NF}=$ Niuafo'ou, $\mathrm{T}=$ Tongatapu, and $\mathrm{V}=$ Vava'u. CLSC and ELSC $=$ Central Lau and Eastern Lau spreading centers, respectively. MTJ = Mangatolu Triple Junction, VF = Valu Fa Ridge, and Z = Zephyr Shoal. The location of DSDP Site 203 is shown as an open box. Contour intervals in kilometers. 
was confirmed through the use of some poorly preserved specimens extracted from the samples.

Larger foraminifers are normally studied by means of thin sections so that the internal morphologic features used for taxonomic purposes can be determined. Though oriented sections are the most useful, it is often not possible to obtain such sections. The degree of cementation may not permit the extraction of specimens, or other problems, such as the extreme delicacy of the specimens, may prevent this method of study. For this study, random thin sections were used because the extracted larger foraminifers were fractured during disaggregation; also, some samples were too well cemented for larger foraminifers to be extracted successfully. For these reasons, this study is based mainly on random thin sections. Disaggregation of samples was achieved by soaking the samples in a mixture of hydrogen peroxide and sodium hexametaphosphate (Calgon) and then washing them over a $63-\mu \mathrm{m}$ sieve. Table 1 illustrates the distribution of larger benthic foraminifers within all samples studied. All figured specimens have been stored in the Commonwealth Palaeontological Collection at the Australian Geological Survey Organisation, Canberra; catalog numbers are prefixed CPC.

\section{LARGER FORAMINIFER DISTRIBUTION}

\section{Eocene}

Larger foraminifers are present in samples from Cores 135-841B$47 \mathrm{R}$ and $-46 \mathrm{R}$. The lowest sample (135-841B-47R-2, 92-96 cm), contains Amphistegina waiareka (Plate 3, Figs. 6-7), Asterigerina tentoria (Plate 3, Fig. 9), Asterocyclina matanzensis (Plate 4, Figs. 6-7), Discocyclina omphala (Plate 3, Fig. 18; Plate 4, Figs. 1-5), Operculina pacifica (Plate 3, Fig. 10), and Sherbornina carteri (Plate 3, Figs. 4-5). Halkyardia ?minima (Plate 3, Fig. 8) occurs in Sample 135-841B-47R$1,92-96 \mathrm{~cm}$. Also present in these samples are the planktonic foraminifers Acarinina, Globigerinatheka (Plate 3, Fig. 2), and Morozovella (Plate 3, Fig. 3). This benthic assemblage continues to Sample 135841B-46R-CC, but the benthic species gradually increase in numbers and planktonic species disappear. Articulated calcareous algae, bryozoa, and echinoid fragments are also present; the calcareous algae are rare in the lower beds but become the dominant bioclast in Sample 135-841B-46R-CC; nodular calcareous algae and Halimeda (Plate 3, Fig. 17) are present only in Sample 135-841B-46R-CC. Throughout the rest of Core 135-841B-46R, the larger foraminifer faunas revert to being similar to those of Core 135-841B-47R, but the discocyclinids are thinner and larger in diameter; being delicate, the tests are fragmented and distorted (Plate 2, Figs. 1-4). Heterostegina saipanensis (Plate 3, Fig. 11), Nummulites pengaronensis (Plate 3, Figs. 14-15), and Spiroclypeus vermicularis (Plate 3, Figs. 12-13) are distributed sporadically. Planktonic foraminifers are rare in most samples, with Globigerinatheka sp. (Plate 3, Fig. 1) and questionable Subbotina eocaena being recorded; no Acarinina or Morozovella were recorded above Sample 135-841B-47R-1, 92-96 cm. From Sample 135-841B$46 \mathrm{R}-1,35-39 \mathrm{~cm}$, planktonic foraminifer assemblages become more diverse and permit accurate zonal assignment. Articulated coralline algae, which may be locally abundant, are present in all samples (except for Sample 135-841B-45R-CC) that also contain larger foraminifers. Sample 135-841B-45R-CC, which is the highest with larger foraminifers, contains only a few specimens of Discocyclina. All samples from which larger foraminifers have been found are bioclastic packstones (Plate 1, Figs. 1-4; Plate 2, Figs. 1-4), with a large proportion of volcanic lithoclasts, and with the matrix probably composed of products of the breakdown of volcanic materials.

\section{Middle Miocene}

Only two samples were found to contain larger foraminifers in middle Miocene Unit IV. Sample 135-841B-41R-2, 110-114 cm, contains fragments of Cycloclypeus sp. (Plate 4, Fig. 8) and Lepidocyclina (Nephrolepidina) ?howchini (Plate 4, Fig. 13), together with
Amphistegina radiata (Plate 4, Fig. 10), Sphaerogypsina globula (Plate 4, Fig. 9), articulated coralline algae, and calcareous lithoclasts containing foraminifers and coralline algae. Sample 135-841B-40R$4,23-27 \mathrm{~cm}$, contains $A$. radiata, articulated coralline algae, and some molluscan fragments. Both samples contain planktonic foraminifers (Chaproniere and Nishi, this volume) typical of Zone N8.

\section{Late Miocene}

Larger foraminifers have been found over the interval from Sample $135-841 \mathrm{~B}-22 \mathrm{R}-3,10-14 \mathrm{~cm}$, to $-20 \mathrm{R}-2,111-115 \mathrm{~cm}$. These are from a sequence of volcanic conglomerates and sandstones. The foraminifers are found as rare fragments in the matrix or within some of the rare sedimentary-derived lithoclasts. The assemblages are dominated by Amphistegina ?waiareka (Plate 4, Fig. 11) and fragments of discocyclinids. Nummulites pengaronensis, Operculina pacifica, and Pellatispira madaraszi (Plate 5, Figs. 4-5) are also present. Two samples (135-841B-22R-3, 10-14 cm, and -22R-2, 146-150 cm), contain articulated and nodular coralline algae. Planktonic foraminifers are very rare throughout this part of the section, but single specimens of Pulleniatina sp. (Plate 5, Fig. 1) and Globorotalia (Globorotalia) tumida ?plesiotumida (Plate 5, Fig. 2) were found in Sample 135841B-20R-3, 66-69 cm.

\section{BIOSTRATIGRAPHY}

The planktonic zonal scheme used in this paper (Fig. 2) is based on Blow (1969) with modifications made by Kennett and Srinivasan (1983). The larger foraminifer assemblages are correlated with the Letter Stage scheme (Adams, 1983, 1984; Adams et al., 1986). The time scale is that of Berggren, Kent, and Flynn (1985); Berggren, Kent, and van Couvering (1985); and Berggren and Miller (1988).

\section{Eocene}

The presence of Acarinina and Morozovella in samples from Core 135-841B-47R indicate that these beds cannot be younger than Zone $\mathrm{P} 14$, suggesting that these larger foraminifer assemblages are from the $\mathrm{T} a_{3}$ Letter Stage (Adams et al., 1986). In contrast, the absence of Acarinina and Morozovella, and the presence of faunas typical of Zone P15 or P16 in samples from Core 135-841B-46R (Nishi and Chaproniere, this volume) indicate that the larger foraminifer assemblages should be assigned to the T $b$ Letter Stage. Pellatispira, the presence of which defines the T $b$ Letter Stage, is absent from beds of Unit V. Spiroclypeus vermicularis, which appears to be also restricted to the T $b$ Letter Stage (Adams, 1970), is present from the base of Core 135-841B-46R. The planktonic foraminifer assemblages suggest that a stratigraphic break occurs within the sequence between Cores 135-841B-46R and -47R; this break may be caused by faulting or by a hiatus. Sample 135-841B-46R-CC contains rare unidentifiable planktonic foraminifers, making its zonal assignment uncertain. The presence of $S$. vermicularis in this sample suggests that any break must be below the base of Core 135-841B-46R. Several faults are present within the stratigraphic sequence at Site 841 (Parson, Hawkins, Allan, et al., 1992), although no faults have been recorded near this level. Elsewhere in the Indo-Pacific, the $\mathrm{T} a_{3} / \mathrm{T} b$ Letter Stage boundary is marked by a hiatus. Adams et al. (1986) pointed out that Vail et al. (1977) had postulated a sea-level fall at the P14/P15 zonal boundary (which is supported by Haq et al., 1988); for this reason, they equated the $\mathrm{T} a_{3} / \mathrm{T} b$ Letter Stage boundary with the P14/P15 boundary. Thus, the evidence suggests that a hiatus, rather than a fault, may separate the $\mathrm{T} a_{3}$ and $\mathrm{T} b$ Letter Stages at Site 841 .

Sherbornina carteri was described by Chaproniere (1983) from the Coral Sea area, from similar assemblages to those of the lower part of Unit V, below Sample 135-841B-46R-CC (i.e., from the $\mathrm{T} a_{3}$ Letter Stage). Its presence with S. vermicularis in Sample 135-841B$46 \mathrm{R}-\mathrm{CC}$ suggests that it also ranges into the T $b$ Letter Stage. 
Table 1. Chart showing distribution of larger and selected benthic and planktonic foraminifers from Site 841.

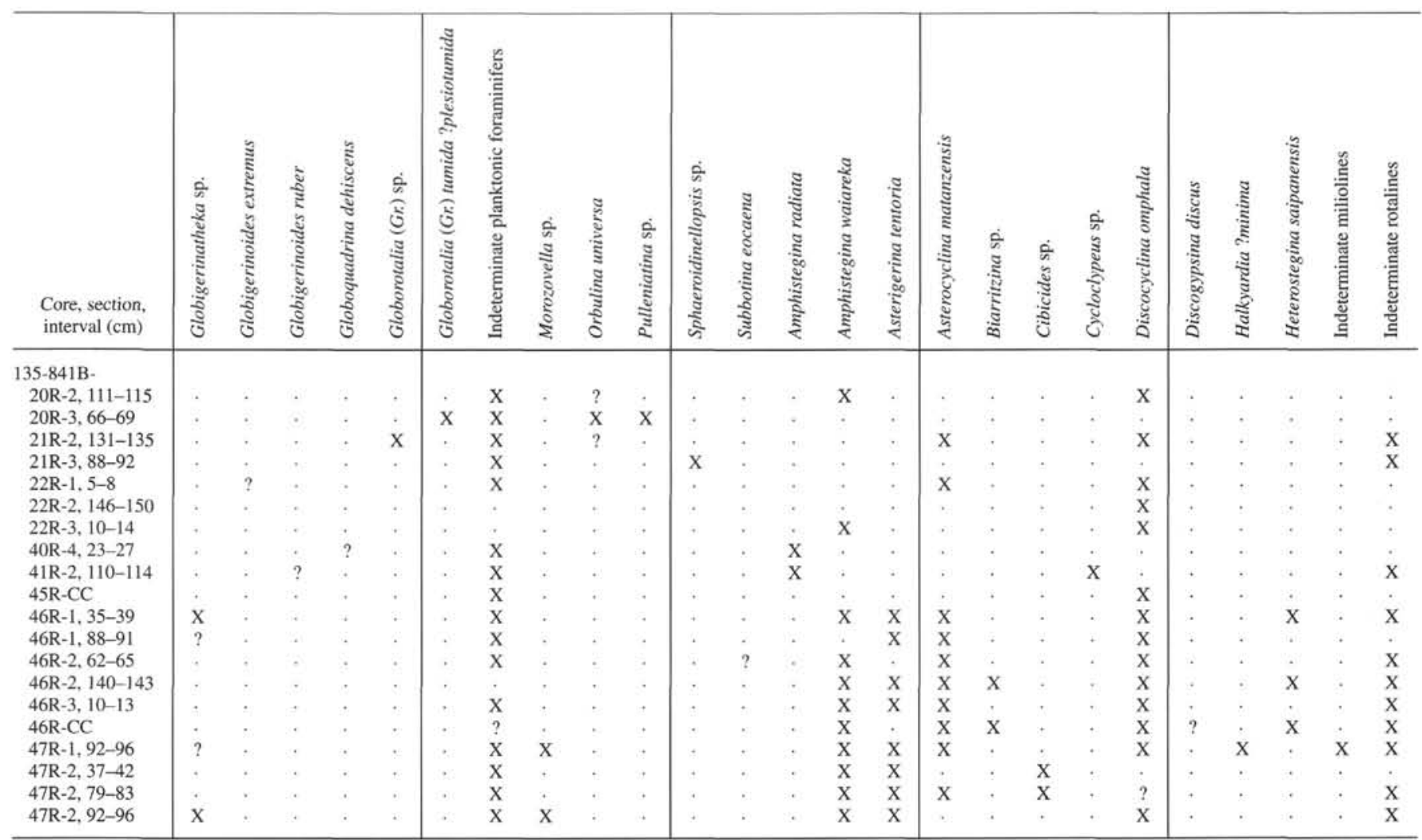

\section{Middle Miocene}

Planktonic foraminifers from Unit IV indicate that it ranges from Zones N8 to N9 (Chaproniere and Nishi, this volume). The two samples with shallow-water biotic material are from the lower part of Unit IV, within Zone N8. Although the larger foraminifers are not age diagnostic, the presence of $L$. (N.) ?howchini sensu lato indicates the interval $\mathrm{T} e_{5}$ to $\mathrm{T} f_{1}$. However, because of the rarity of larger foraminifers at these levels, no better resolution can be made on the basis of these faunas.

\section{Late Miocene}

As noted above, the presence of Pellatispira indicates the $\mathrm{T} b$ Letter Stage. This genus is present in two late Miocene samples, suggesting that these bioclasts were derived from a $\mathrm{T} b$ source. The presence of Pulleniatina in one sample (135-841B-20R-3, 66-69 cm) indicates that at least part of the section with Eocene larger foraminifers is no older than Zone N17B, and that most of the lower part of Unit III is probably no older than Zone N17A. Unfortunately, both planktonic foraminifer and calcareous nannofossil assemblages over this interval are few and not age diagnostic.

\section{DISCUSSION}

In Unit V, the Eocene/Oligocene boundary is almost certainly represented by a hiatus, based on the planktonic foraminifer evidence (Nishi and Chaproniere, this volume). On the basis of the planktonic foraminifers, most of the interval covered by Core 135-841B-46R should contain a $\mathrm{T} b$ Letter Stage assemblage, but the index, Pellatispira, is absent; however, Spiroclypeus vermicularis, which seems to be restricted to the T $b$ Letter Stage (Adams, 1970), is present. As noted above, the larger foraminifers over this interval are dominated by large, fragile specimens of Discocyclina; in addition, the planktonic foraminifer assemblages gradually become more diverse. Also, given the planktonic foraminifer evidence, the interval from just above Sample 135-841B-46R-CC to $-47 \mathrm{R}-2,92-96 \mathrm{~cm}$, must correlate to the $\mathrm{T} a_{3}$ Letter Stage; if the presence of $S$. vermicularis indicates the $\mathrm{T} b$ Letter Stage, then the absence of Pellatispira from Core 135841B-46R is probably the result of environmental factors.

Adams et al. (1986) discussed the Eocene-Oligocene transition in the Indo-Pacific region. They concluded that for most of the shallowwater sections a hiatus separated the late Eocene and early Oligocene, and that for most deeper water sections the sequence was continuous. They hypothesized that the hiatus was related to a sea-level fall, and that only in those sections deposited in shallow-water, where subsidence took place at the same rate or faster than sea-level fall, would the sequence be continuous over the boundary. As noted above, the Eocene/Oligocene boundary is probably a hiatus in Unit V, but the larger foraminifers disappeared at a level well below the boundary, within the P15 to P16 zonal interval. However, it is not possible to ascertain whether the disappearance of the larger foraminifers was a result of their true extinction or because of environmental factors. The increase in test diameter, the delicacy of the tests, as well as the increase in planktonic foraminifer diversity, suggests that the disappearance was environmental. The subsidence rate was probably greater than sea-level fall at this site, resulting in water depths greater than those that could be tolerated by the larger foraminifers.

The nearest localities where Eocene larger foraminifers are present are found in Fiji (Cole, 1960), 'Eua Island (Cole, 1970; Chaproniere, in press), and the subsurface of Tongatapu Island (Webb Tongan Inc., unpubl. repts., 1978). Only those from Fiji and 'Eua Island have been adequately described. Those from Fiji are typical of the T $b$ Letter Stage, based on the presence of Pellatispira (Cole, 1960). On 'Eua Island, two distinct larger foraminifer assemblages are present. One of these assemblages, which contains Asterocyclina matanzensis, 


\begin{tabular}{|c|c|c|c|c|c|c|c|c|c|c|c|c|c|c|c|c|}
\hline 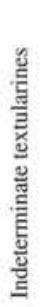 & 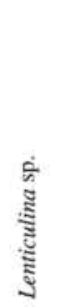 & 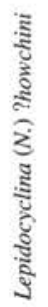 & 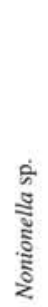 & 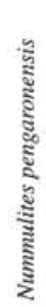 & 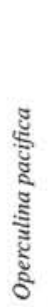 & 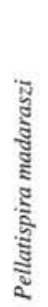 & 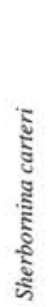 & 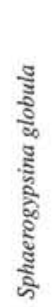 & 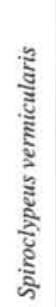 & 悹 & 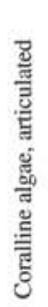 & 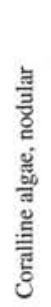 & 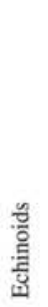 & 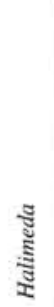 & $\begin{array}{l}\text { 品 } \\
\text { 竞 } \\
\sum\end{array}$ & 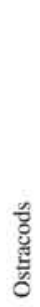 \\
\hline . & . & . & . & $x$ & & $x$ & . & . & . & . & . & . & . & . & . & . \\
\hline . & . & . & . & . & . & . & . & . & . & . & . & . & . & . & . & . \\
\hline . & . & . & . & . & . & & . & & . & . & . & . & $x$ & . & & . \\
\hline . & . & . & . & . & . & & . & & . & & . & . & . & . & & . \\
\hline . & . & , & . & . & . & . & . & . & . & . & . & . & & , & & . \\
\hline . & . & . & . & . & . & $?$ & . & & . & . & $x$ & $\mathrm{X}$ & . & , & $x$ & . \\
\hline . & . & . & . & . & $\mathrm{X}$ & . & . & . & . & $x$ & $x$ & $\mathrm{X}$ & . & . & & . \\
\hline$X$ & . & . & . & . & $\because$ & & . & . & . & . & $\mathrm{x}$ & . & & . & $\mathrm{x}$ & . \\
\hline$x$ & . & $x$ & . & & . & . & . & $x$ & . & . & $x$ & . & . & & . & . \\
\hline & . & . & . & . & . & . & . & . & . & . & . & . & . & & . & . \\
\hline$X$ & . & . & . & . & $\mathrm{X}$ & . & . & $x$ & $X$ & $x$ & $x$ & . & $x$ & & $\mathrm{X}$ & . \\
\hline & . & . & . & $X$ & $\mathrm{X}$ & . & . & $x$ & . & $\mathrm{X}$ & $X$ & . & $\mathrm{X}$ & & $\mathrm{X}$ & . \\
\hline & . & & . & . & $\mathrm{X}$ & . & . & . & & $\mathrm{x}$ & $x$ & . & $x$ & & $\mathrm{X}$ & . \\
\hline$x$ & . & & . & & $\mathrm{x}$ & . & . & $\mathrm{x}$ & . & $\mathrm{X}$ & $\mathrm{x}$ & . & $\mathrm{x}$ & & $\mathrm{x}$ & . \\
\hline$x$ & . & . & . & . & $\mathrm{X}$ & & & . & . & $\mathrm{X}$ & $x$ & . & . & . & $\mathrm{X}$ & . \\
\hline . & . & . & . & . & $x$ & & 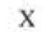 & . & $x$ & $x$ & $x$ & $\mathrm{X}$ & $x$ & $X$ & . & . \\
\hline$X$ & . & . & . & . & $\mathrm{x}$ & . & . & . & . & $x$ & $x$ & . & $x$ & . & . & . \\
\hline . & . & . & $x$ & . & $\mathrm{x}$ & . & . & . & . & $\mathrm{X}$ & . & . & $x$ & . & . & $x$ \\
\hline . & $x$ & . & $\mathrm{x}$ & . & $\mathrm{x}$ & . & . & . & . & $x$ & . & . & $x$ & . & $x$ & $x$ \\
\hline$x$ & . & , & . & . & $\mathrm{x}$ & . & $x$ & . & . & $\mathrm{X}$ & $\mathrm{x}$ & $\mathrm{x}$ & $x$ & . & & . \\
\hline
\end{tabular}

Discocyclina omphala, Heterostegina saipanensis, and Nummulites pengaronensis (Chaproniere, in press), is very similar to that found in the lower part of Unit V. This assemblage is typical of the $\mathrm{T} a_{3}$ Letter Stage and is associated with a Zone P14 planktonic foraminifer fauna. A second fauna, although similar to the one discussed above, but which also contains Pellatispira madaraszi and Spiroclypeus vermicularis and so is typical of the T $b$ Letter Stage, has not been recorded from Unit V. On 'Eua Island this T $b$ Letter Stage assemblage is associated at one locality with a Zone P17 planktonic fauna (Cole, 1970; Chaproniere, in press). The T $b$ Letter Stage faunas from both 'Eua Island and Fiji are present in creamy, foraminifer-algal limestones lacking volcanic debris (Chaproniere, in press), and those from the $\mathrm{T} a_{3}$ Letter Stage on 'Eua Island are associated with a gritty and conglomeratic (volcanic clasts) limestone sequence (Keij and Postuma, 1971) that contains coralline algae (Chaproniere, in press). The volcanic materials in the Zone P14 limestones from 'Eua Island are weathering products from older, preexisting volcanic deposits, a similar mode of origin to those of Site 841 .

The Eocene larger foraminifers found in the lower part of Unit III differ from those of Unit V by the presence of Pellatispira. As noted above, the presence of this genus defines the $\mathrm{T} b$ Letter Stage. The absence of this form from Unit V precludes this as the source for these larger foraminifers. As noted above, the closest occurrence of definite $\mathrm{T} b$ Letter Stage limestones is on the adjacent 'Eua Island. Thus, the most probable source for these reworked faunas is either as weathering products derived from 'Eua Island, or from the same lithologic unit exposed elsewhere in the nearby region. The presence of these faunas indicates that either 'Eua, or some other part of the Tongan Platform, was exposed to subaerial erosion during the late Miocene.

Because of the fragmentation of the larger foraminifers present within the middle Miocene Unit IV, and the dominance of planktonic assemblages, the faunas are clearly reworked into deeper waters and are unlikely to be in situ. Furthermore, the presence of $L$. $(N$.) ?howchini suggests that the specimens may have been derived from older $\mathrm{T} e_{5}$ to $\mathrm{T} f_{1}$ Letter Stage rocks. To date, no assemblages from the $\mathrm{T} e$ Letter Stage have been recorded from the Tongan Platform or Lau Ridge (Cole, 1945), even though they are widespread throughout the Indo-west Pacific region; $\mathrm{T} f_{1}$ faunas have been recorded from Fiji (Chaproniere, 1980), and this may imply that the region was closer to Fiji and the Lau Ridge during the late early Miocene. Nevertheless, the presence of these larger foraminifers implies either erosion of early Miocene carbonates in the vicinity of Site 841 , or redeposition of contemporaneous shallow-water faunas into deeper waters at this site during Zone N8 time.

\section{PALEOBATHYMETRY}

Modern larger foraminifers contain photosynthetic symbionts, and because fossil larger foraminifers have similar morphologic features, it has been postulated that they bear a similar relationship to algae (Chaproniere, 1975; Lee et al., 1979; Hallock, 1982; Lee and Hallock, 1987). This symbiotic relationship would have restricted the depth distribution to within the euphotic zone, which generally is restricted to $100 \mathrm{~m}$ or less. The presence of Halimeda and coralline algae supports a depth range of $<60 \mathrm{~m}$ (Davies and Marshall, 1985). Chaproniere (1975) discussed the depth ranges of early Neogene larger foraminifers, and noted that with increasing depth test diameter increased, as is found for modern Marginopora vertebralis (Ross, 1972).

Throughout Core 135-841B-47R above the rhyolitic sands, larger foraminifers tend to be fragmented and occur with coralline algae (Plate 1, Figs. 1-2); nodular coralline algae are sporadic. Planktonic foraminifers are present, but they represent a small proportion of the foraminifer population. The presence of coralline algae and larger foraminifers suggests depths within the euphotic zone. These depths were probably between 50 and $100 \mathrm{~m}$. The only sample to contain Halimeda and nodular coralline algae is Sample 135-841B-46R-CC (Plate 

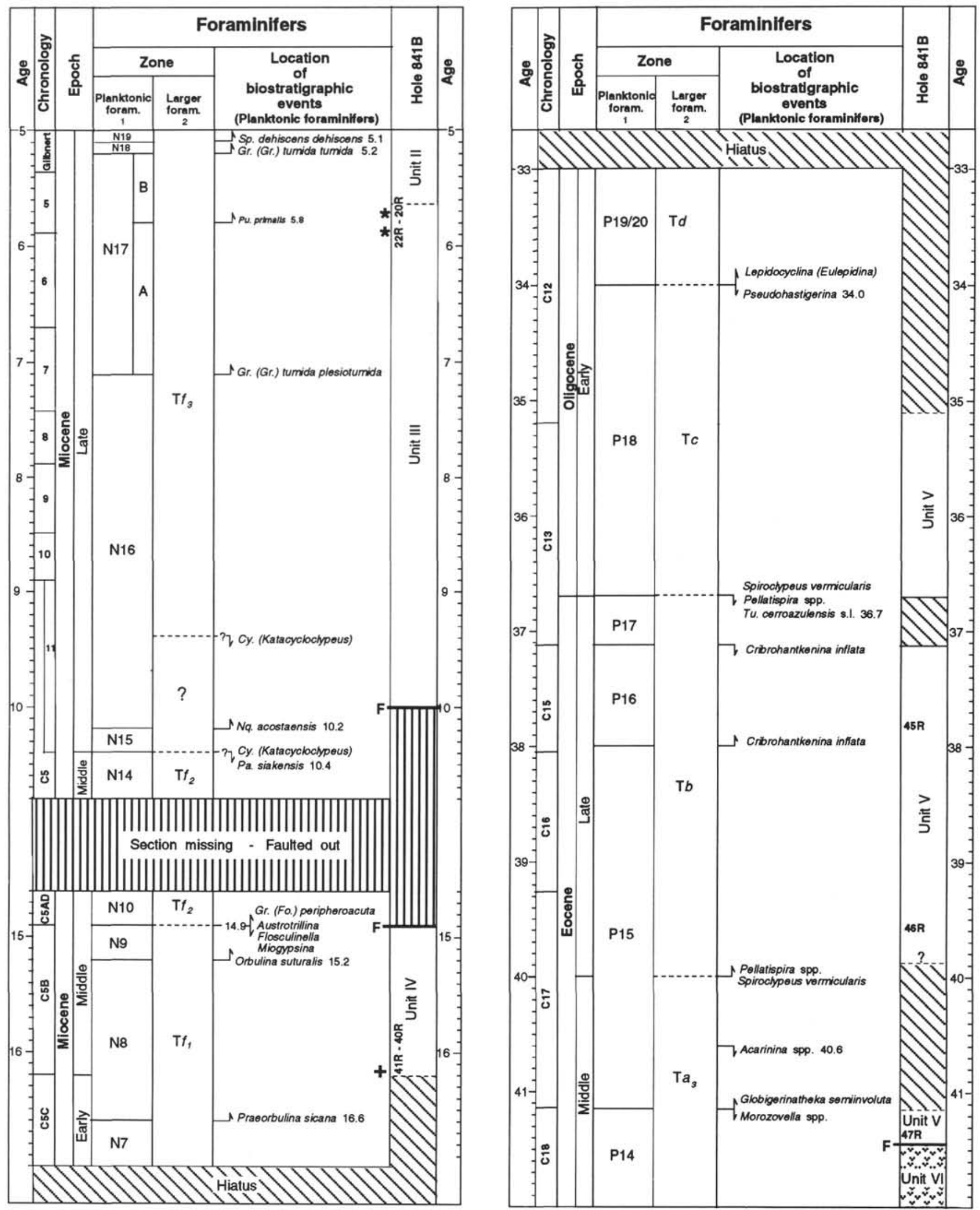

Figure 2. Biostratigraphic summary of Hole 841B, from Units II to V. Cy. =Cycloclypeus, Ga.$=$ Globigerina, Go. $=$ Globoturborotalita, Gr $=$ Globorotalia, Fo . $=$ Fohsella, $\mathrm{Nq} .=$ Neogloboquadrina, $\mathrm{Pa} .=$ Paragloborotalia, $\mathrm{Pu} .=$ Pulleniatina, $\mathrm{Sp} .=$ Sphaeroidinella,$T u .=$ Turborotalia $. *=$ presence of reworked larger foraminifers, $+=$ presence of reworked ?early Miocene larger foraminifers. Sources of data: $1=$ Berggren and Miller (1988); $2=$ Adams (1970, 1983) and Chaproniere $(1983,1984)$. 
1, Figs. 3-4); this also contains the most diverse and abundant larger foraminifers as well as a sparse planktonic assemblage. Because similar modern associations in the Great Barrier Reef of Australia are typical of water depths of 50-60 m (Davies and Marshall, 1985), one can conclude that this Eocene assemblage was typical of similar depths. The large-diameter, fragile tests of Asterocyclina and Discocyclina in samples higher in Core 135-841B-46R (Plate 2, Figs. 1-4) suggest an increase in water depths toward the limit of the euphotic zone at approximately $100 \mathrm{~m}$; the presence of articulated coralline algae and the low proportion of planktonic species would add support to this conclusion. The presence of planktonic species throughout most of the Eocene sequence containing larger foraminifers (Cores 135-46R and $-47 \mathrm{R}$ ), the presence of Amphistegina, and the low proportion of miliolines, suggest that water salinity values were at normal oceanic levels (Murray, 1973); the presence of Halimeda suggests tropical surface-water temperatures (Lees, 1975; Lees and Buller, 1972).

As noted above, the larger benthic foraminifer assemblages found in Unit IV are too poor to permit accurate depth assessments, but they have clearly been reworked into deeper waters from distinctly shallow-water environments. The presence of Amphistegina suggests that the water salinity values were at normal oceanic levels.

\section{CONCLUSIONS}

The larger foraminifer assemblages from Core 135-841B-47R lack Pellatispira and Spiroclypeus vermicularis and are typical of the $\mathrm{T} a_{3}$ Letter Stage. The presence of a Zone P14 planktonic assemblage supports this age determination. The larger foraminifer assemblage from Core 135-841B-46R lacks Pellatispira but contains $S$. vermicularis and so is typical of the $\mathrm{T} b$ Letter Stage. The presence of Zones P15 to P16 planktonic foraminifers supports this assessment.

A hiatus is present between the base of Core 135-841B-46R and the top of Core 135-841B-47R that probably corresponds with a sea-level fall at this time. The water depth at the time that Core $135-841 \mathrm{~B}-47 \mathrm{R}$ was deposited ranged from 50 to $100 \mathrm{~m}$. The water depth at the base of Core 135-841B-46R was between 50 and $60 \mathrm{~m}$, gradually increasing to about $100 \mathrm{~m}$ at the base of Core $135-841 \mathrm{~B}$ $45 \mathrm{R}$; above this, depths were too great to permit the existence of larger foraminifers. Surface-water temperatures were tropical, at least for the interval over which the larger foraminifers occur.

Amphistegina radiata, Cycloclypeus sp., and Lepidocyclina (Nephrolepidina) ?howchini are present within the lower part of Unit IV, within Zone N8. The high planktonic foraminifer species diversity and the presence of limestone lithoclasts suggests that the larger foraminifers were either reworked from older shallow-water deposits, possibly of early Miocene age ( $\mathrm{T}_{5}$ Letter Stage), or they may have been derived from contemporaneous shallow-water sediments. The absence of $\mathrm{T} e_{5}$ faunas in the region and the occurrence of $\mathrm{T} f_{1}$ assemblages in Fiji suggest that the latter explanation is the most probable. Larger foraminifers within the conglomeratic phase of Unit III contain both Pellatispira madaraszi and Spiroclypeus vermicularis, indicating the $\mathrm{T} b$ Letter Stage. The planktonic foraminifers, though rare and sporadic, suggest Zones N17A or N17B, indicating that the larger foraminifers have been reworked.

The nearest locality that contains the larger foraminifer assemblage with Pellatispira is 'Eua Island. These faunas may have been derived from this or another nearby source, probably by subaerial weathering, indicating that part of the Tongan Platform was exposed during the late Miocene. Site 841 has subsided from water depths of approximately $50 \mathrm{~m}$ during the middle and late Eocene to depths below the CCD by the late Miocene (Zone N17).

\section{ACKNOWLEDGMENTS}

I thank the reviewers of the manuscript for their comments. This paper is published with the permission of the Executive Director, Australian Geological Survey Organisation, Canberra, Australia.

\section{REFERENCES}

Adams, C.G., 1970. A reconsideration of the East Indian Letter Classification of the Tertiary. Bull. Brit. Mus. (Nat. Hist.), Geol., 19:85-137.

, 1983. Speciation, phylogenesis, tectonism, climate and eustasy: factors in the evolution of Cenozoic large foraminiferal bioprovinces. In Sims, R.W., Price, J.H., and Whalley, P.E.S. (Eds.), Evolution, Time and Space: The Emergence of the Biosphere. Systematics Assoc. Spec. Vol., 23:255-289.

1984. Neogene larger foraminifera, evolutionary and geological events in the context of datum planes. In Ikebe, N., and Tsuchi, R. (Eds.), Pacific Neogene Datum Planes. Contributions to Biostratigraphy and Chronology: Tokyo (Univ. Tokyo Press), 47-67.

Adams, C.G., Butterlin, J., and Samanta, B.K., 1986. Larger Foraminiferida and events at the Eocene/Oligocene boundary in the Indo-West Pacific region. In Pomerol, C., and Premoli Silva, I. (Eds.), Terminal Eocene Events: Amsterdam (Elsevier), 237-252.

Berggren, W.A., Kent, D.V., and Flynn, J.J., 1985. Jurassic to Paleogene: Part 2. Paleogene geochronology and chronostratigraphy. In Snelling, N.J. (Ed.), The Chronology of the Geological Record. Mem. Geol. Soc. London, 10:141-195.

Berggren, W.A., Kent, D.V., and van Couvering, J.A., 1985. The Neogene: Part 2. Neogene geochronology and chronostratigraphy. In Snelling, N.J. (Ed.), The Chronology of the Geological Record. Mem. Geol. Soc. London, 10:211-250.

Berggren, W.A., and Miller, K.G., 1988. Paleogene tropical planktonic foraminiferal biostratigraphy and magnetobiochronology. Micropaleontology, $34: 362-380$

Blow, W.H., 1969. Late middle Eocene to Recent planktonic foraminiferal biostratigraphy. In Brönnimann, P., and Renz, H.H. (Eds.), Proceedings of the First International Conference on Planktonic Microfossils, Geneva, 1967: Leiden (E.J. Brill), 199-421.

Chaproniere, G.C.H., 1975. Palaeoecology of Oligocene-Miocene larger Foraminiferida, Australia. Alcheringa, 1:37-58.

1980. Influence of plate tectonics on the distribution of late Palaeogene to early Neogene larger foraminiferids in the Australasian region. Palaeogeogr., Palaeoclimatol., Palaeoecol., 31:299-317.

, 1983. Tertiary larger foraminiferids from the northwestern margin of the Queensland Plateau, Australia. Bull. Bur. Miner. Resour., Geol. Geophys. (Aust.), 217:61-57.

1984. The Neogene larger foraminiferal sequence in the Australian and New Zealand regions, and its relevance to the East Indian Letter Stage classification. Palaeogeogr., Palaeoclimatol., Palaeoecol., 46:25-35.

-, in press. Middle and late Eocene, Neogene and Quaternary foraminiferal faunas from 'Eua and Vaváu islands, Tonga Group. In Ballance, P.F., Herzer, R.H., and Vallier, T.L. (Eds.), Contributions to the Geology of the Tonga and Lau Regions of the Southwest Pacific. Circum-Pac. Counc. Energy Miner. Resour., Earth Sci. Ser.

Cole, W.S., 1945. Larger foraminifera. In Ladd, H.S., and Hoffmeister, J.E. (Eds.), Geology of Lau, Fiji. Bernice P. Bishop Mus., Bull., 181:272-297.

, 1960. Upper Eocene and Oligocene larger foraminifera from Viti Levu, Fiji. Geol. Surv. Prof. Pap., U.S. 374-A:1-7.

1970. Larger foraminifera of late Eocene age from 'Eua, Tonga. Geol. Surv. Prof. Pap., U.S. 640-B:1-17.

Davies, P.J., and Marshall, J., 1985. Halimeda bioherms-low energy reefs, northern Great Barrier Reef. Proc. 5th Internat. Coral Reef Sym., 5:1-7.

Hallock, P., 1982. Evolution and extinction in larger Foraminifera. Proc. 3rd North Am. Paleontol. Conv., 1:221-225.

Haq, B.U., Hardenbol, J., and Vail, P.R., 1988. Mesozoic and Cenozoic chronostratigraphy and cycles of sea-level change. In Wilgus, C.K., Hastings, B.S., Kendall, C.G.St.C., Posamentier, H.W., Ross, C.A., and Van Wagoner, J.C. (Eds.), Sea-Level Changes-An Integrated Approach. Spec. Publ.-Soc. Econ. Paleontol. Mineral., 42:71-108.

Keij, A.J., and Postuma, J.A., 1971. Palaeontological results. In Mulder, C.J., and Nieuwenhuizen, C.V.D. (Eds.), Appraisal of the Tonga Concession and Recommendations for Future Work. BIPM Explor. Prod. Rep., E.P. 42347:1-5.

Kennett, J.P., and Srinivasan, M.S., 1983. Neogene Planktonic Foraminifera: A Phylogenetic Atlas: Stroudsburg, PA (Hutchinson Ross).

\footnotetext{
Abbreviations for names of organizations and publication titles in ODP reference lists follow the style given in Chemical Abstracts Service Source Index (published by American Chemical Society).
} 
Lee, J.J., and Hallock, P., 1987. Algal symbiosis as the driving force in the evolution of the larger foraminifera. Annu. N.Y. Acad. Sci., 503:330-347.

Lee, J.J., McEnery, M.E., Kahn, E.G., and Schuster, F.L., 1979. Symbiosis and the evolution of larger foraminifera. Micropaleontology, 25:118-140.

Lees, A., 1975. Possible influence of salinity and temperature on modern shelf carbonate sedimentation. Mar. Geol., 19:159-198.

Lees, A., and Buller, A.T., 1972. Modern temperate-water and warm-water shelf carbonate sediments contrasted. Mar. Geol., 13:M67-M73.

Murray, J.W., 1973. Distribution and Ecology of Living Benthic Foraminiferids: London (Heinemann Educational).

Parson, L., Hawkins, J., Allan, J., et al., 1992. Proc. ODP, Init. Repts., 135: College Station, TX (Ocean Drilling Program).

Ross, C.A., 1972. Biology and ecology of Marginopora vertebralis Foraminiferida, Great Barrier Reef. J. Protozool., 19:181-192.

Vail, P.R., Mitchum, R.M., Jr., Todd, R.G., Widmier, J.M., Thompson, S., III, Sangree, J.B., Bubb, J.N., and Hatlelid, W.G., 1977. Seismic stratigraphy and global changes of sea level. AAPG Mem., 26:49-212.

Date of initial receipt: 24 August 1992

Date of acceptance: 23 November 1992

Ms 135SR-118

\section{LIST OF FORAMINIFERS}

\section{Benthic Foraminifers}

Amphistegina radiata (Fichtel and Moll, 1798) (Plate 4, Fig. 10)

Amphistegina waiareka (Finlay, 1939) (Plate 3, Figs. 6-7; Plate 4, Fig. 11)
Asterigerina tentoria Todd and Post, 1954 (Plate 3, Fig. 9) Asterocyclina matanzensis Cole, 1957 (Plate 4, Figs. 6-7)

Cycloclypeus sp. (Plate 4, Fig. 8)

Discocyclina omphala (Fritsch, 1875) (Plate 3, Fig. 18; Plate 4, Figs. 1-5)

Discogypsina discus (Goës, 1896) (Plate 3, Fig. 16)

Halkyardia ?minima (Leibus, 1911) (Plate 3, Fig. 8)

Heterostegina saipanensis Cole, 1953 (Plate 3, Fig. 11)

Lepidocyclina (Nephrolepidina) ?howchini Chapman and Crespin, 1932 (Plate 4, Fig. 13)

Nummulites pengaronensis Verbeek, 1871 (Plate 3, Figs. 14-15)

Operculina pacifica Whipple, 1932 (Plate 3, Fig. 10)

Pellatispira madaraszi (Hantken, 1876) (Plate 5, Figs. 4-5)

Sherbornina carteri Chaproniere, 1983 (Plate 3, Figs. 4-5)

Sphaerogypsina globula (Reuss, 1848) (Plate 4, Fig. 9)

Spiroclypeus vermicularis Tan, 1937 (Plate 3, Figs. 12-13)

\section{Planktonic Foraminifers}

Acarinina sp.

Globigerinatheka sp. (Plate 1, Figs. 1-2)

Globigerinoides extremus Bolli and Bermudez, 1965

Globigerinoides ruber (d'Orbigny, 1839)

Globoquadrina dehiscens (Chapman, Parr and Collins, 1934)

Globorotalia (Gr.) tumida ?plesiotumida Blow and Banner, 1965 (Plate 5, Fig. 2)

Morozovella sp. (Plate 1, Fig. 3)

Orbulina universa d'Orbigny, 1839

Pulleniatina sp. (Plate 5, Fig. 1)

Subbotina eocaena (Gümbel, 1868) 


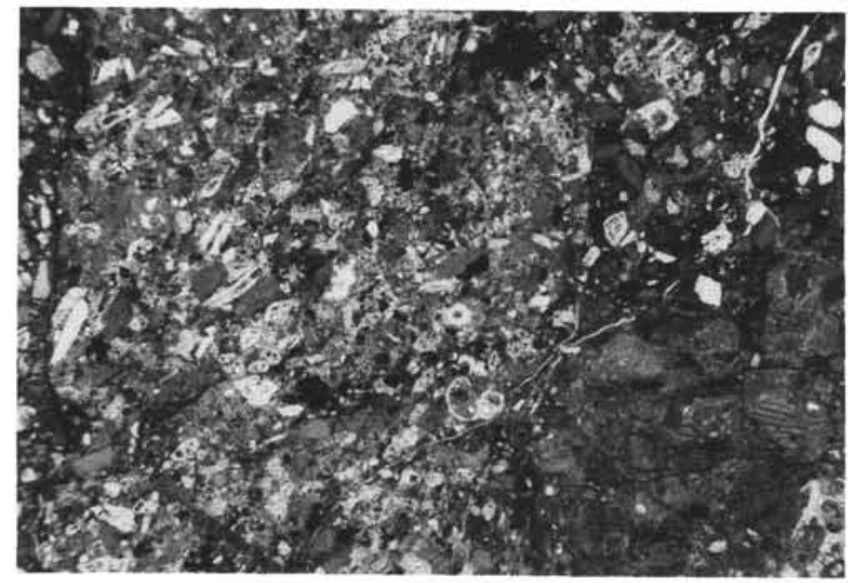

1

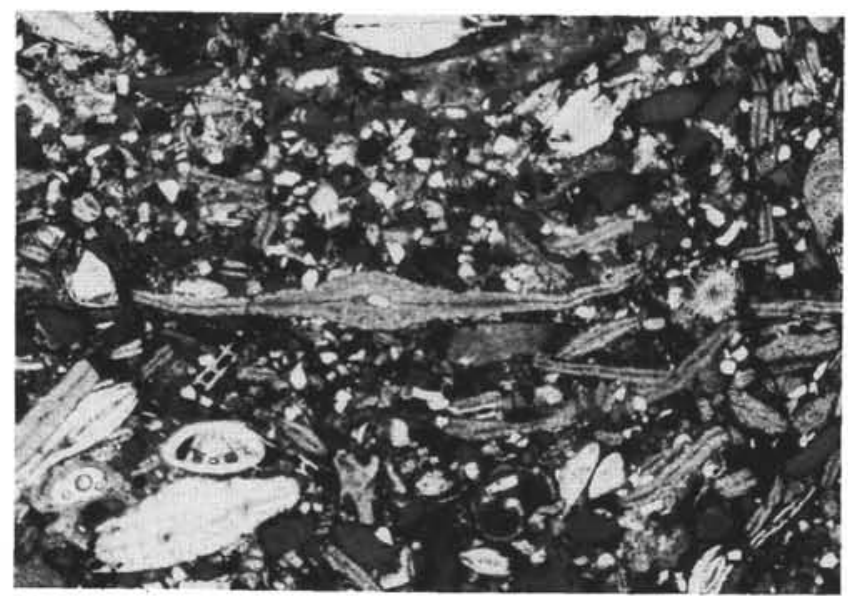

3

Plate 1. 1-4. Micrographs of samples moving up through Core 135-841B-47R to the lowermost sample of Core 135-841B-46R that illustrate the general lithologies of Unit V, the gradual increase in the size of the bioclasts, and the amount of larger foraminifer and coralline algal components. 1. Micrograph of Sample 135-841B-47R-2, 92-96 cm, showing fragments of foraminifers and other bioclastic debris in a fine, mud matrix; black areas are volcanic debris. 2. Micrograph of Sample 135-841B-47R-1, 92-96 cm, showing fragments of foraminifers and other bioclastic debris in a fine, mud matrix; bioclastic material slightly coarser than the previous sample. 3. Micrograph of Sample 135-84IB-46R-CC illustrating fragmentary and intact larger benthic foraminifer bioclasts, together with coralline algae. 4. Same sample, showing part of a coralline algal nodule. The larger benthic foraminifers are dominated by Discocyclina omphala and operculines. Magnifications are all $\times 12$.

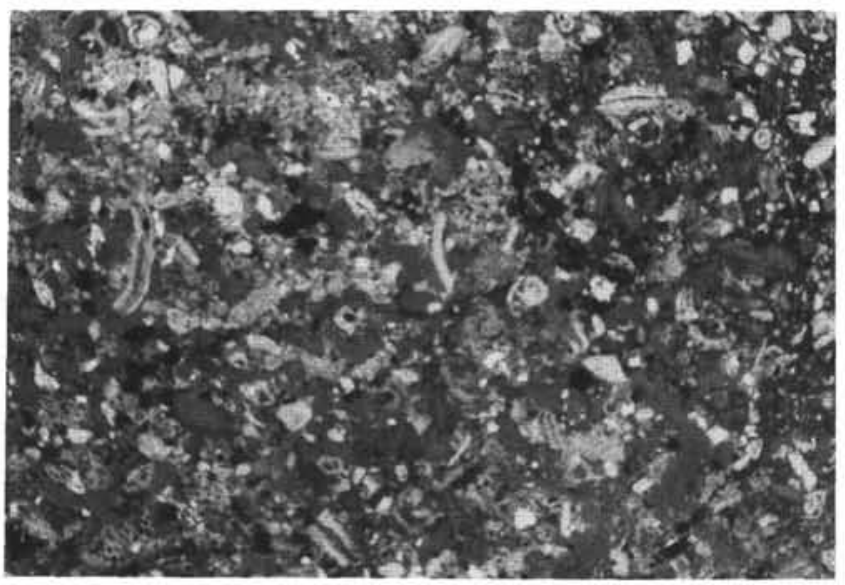

2

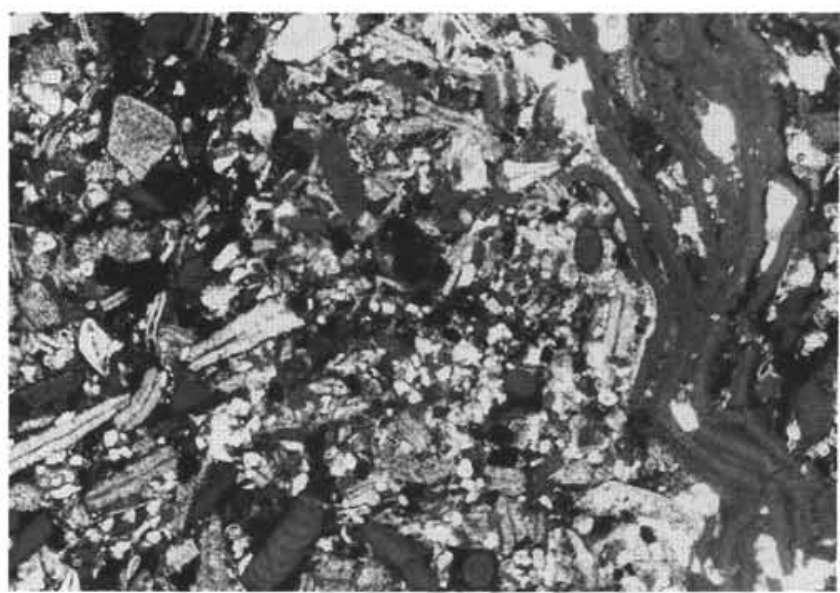

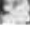

4 


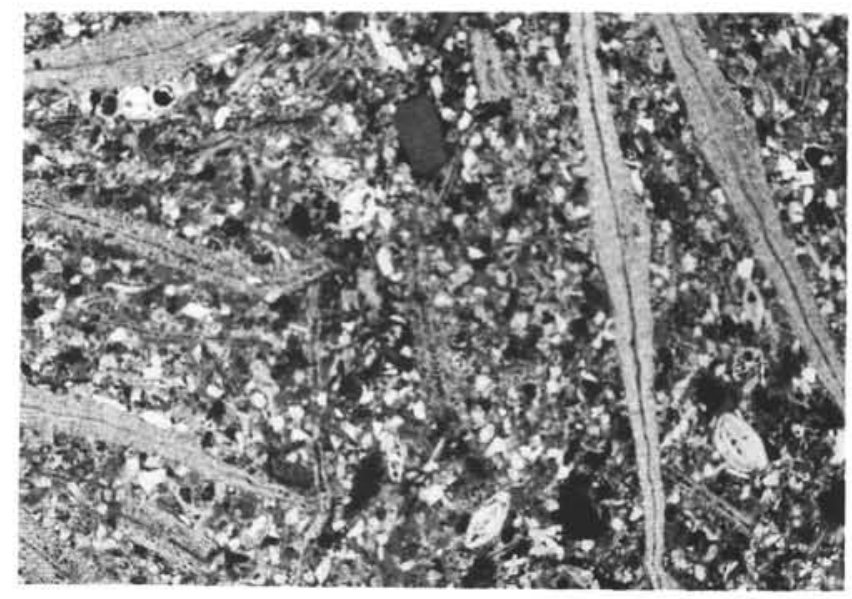

1

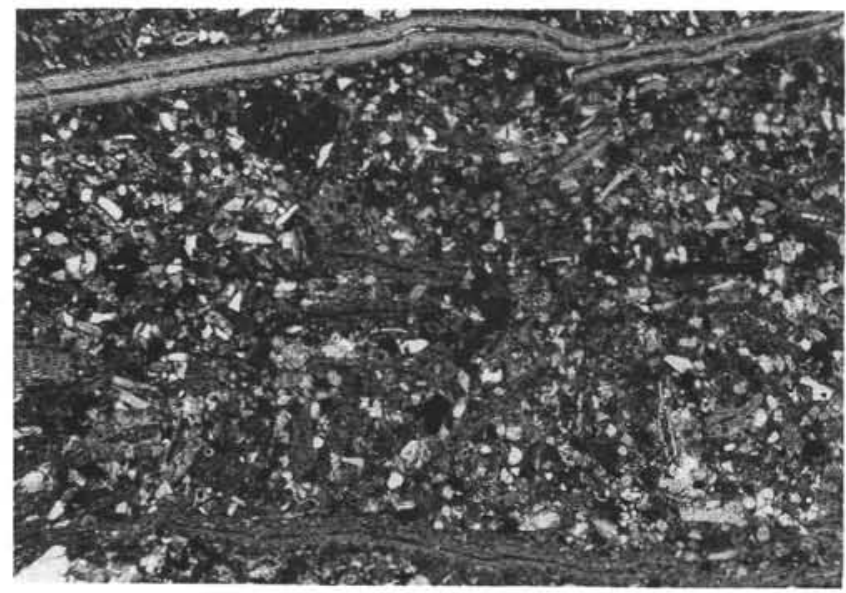

3

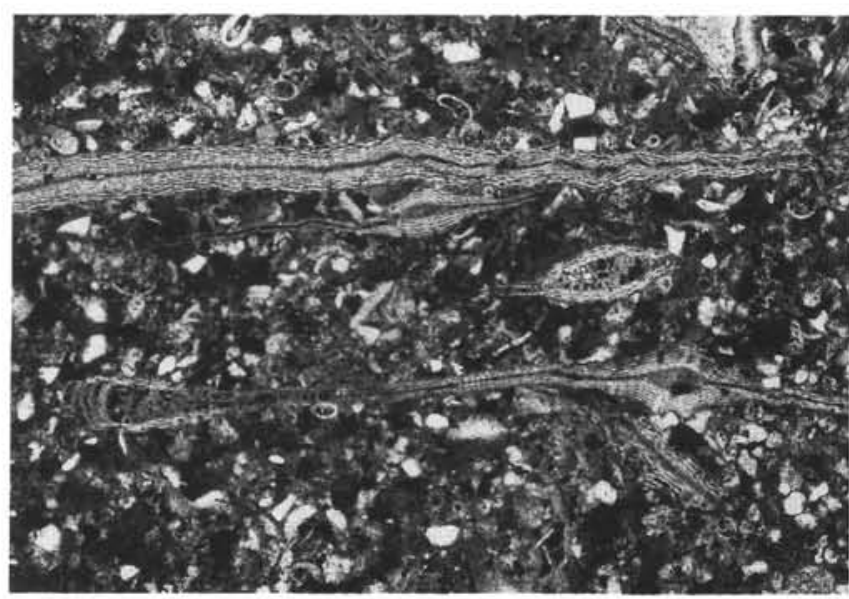

2

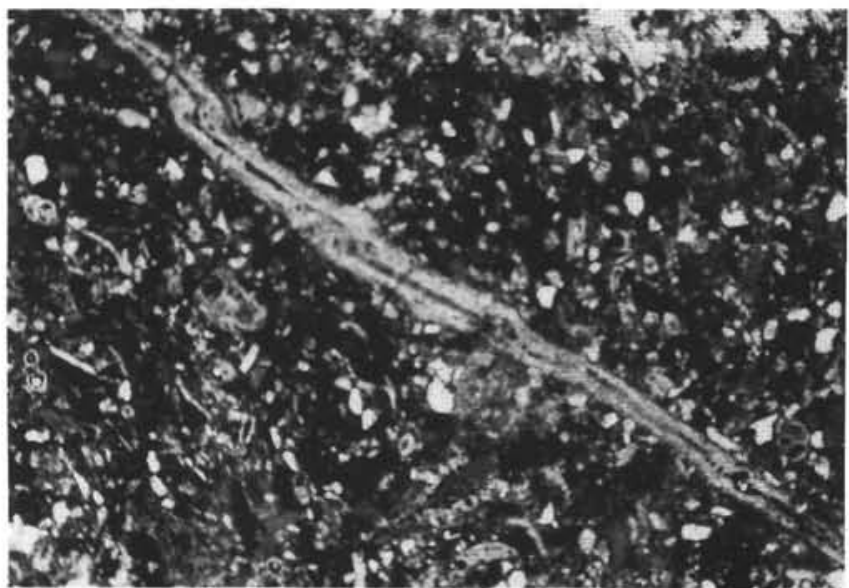

4

Plate 2. 1-4. Micrographs of samples moving up through Core 135-841B-46R illustrating the general lithologies of Unit V, the gradual increase in the amount of the mud-sized fraction, and the decline in the number of larger foraminifer and coralline algal components. Note the large size and delicate nature of the specimens of Discocyclina omphala, which have been distorted and broken after deposition, and which must be in situ. 1. Sample 135-841B-46R-3, 10-13 cm. 2. Sample 135-841B-46R-2, 140-142 cm. 3. Sample 135-841B-46R-2, 62-65 cm. 4. Sample 135-841B-46R-1, 88-91 cm. Magnifications are all $\times 12$. 


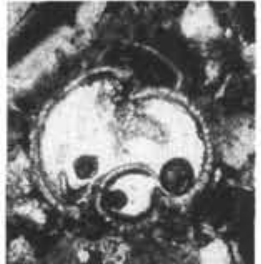

1
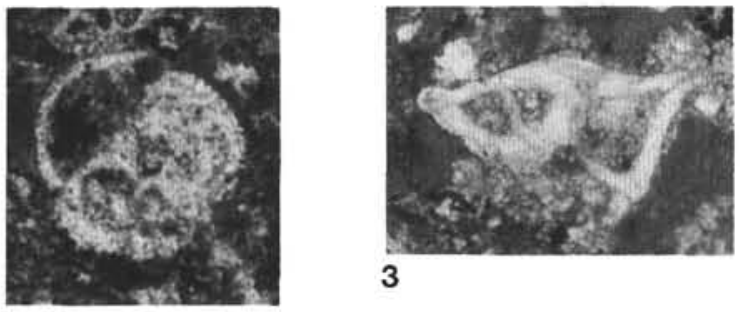

3

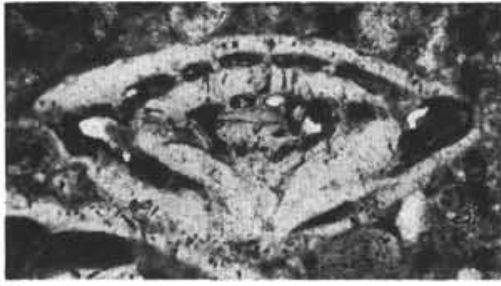

6

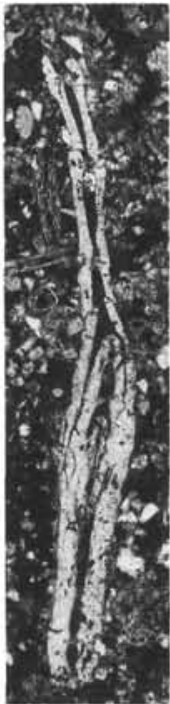

10

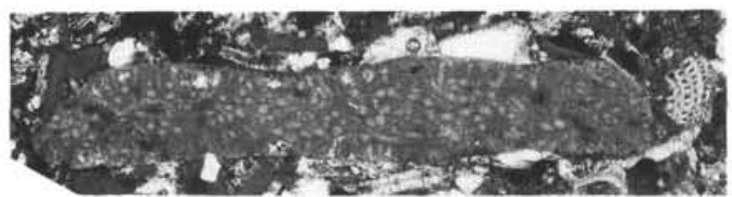

17

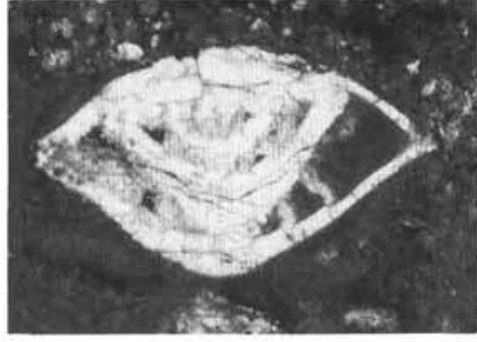

7
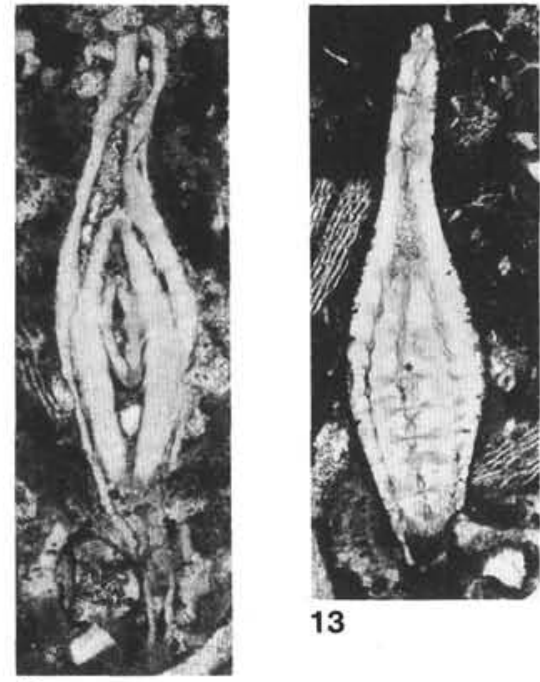

13
18

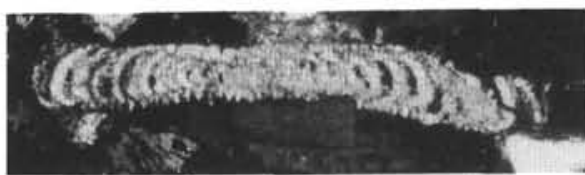

4

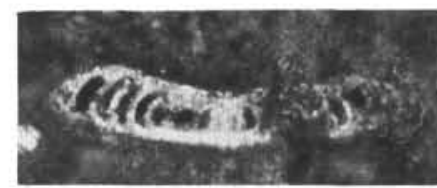

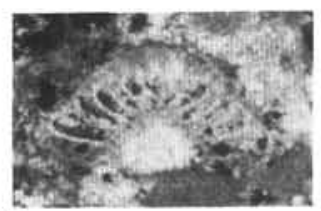

8

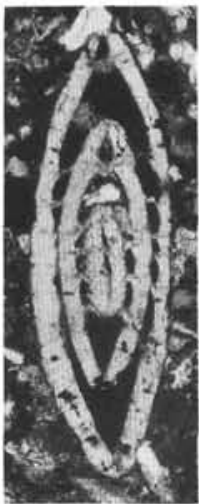

14

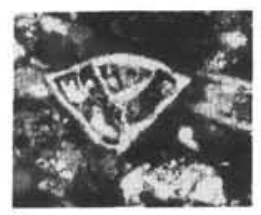

9

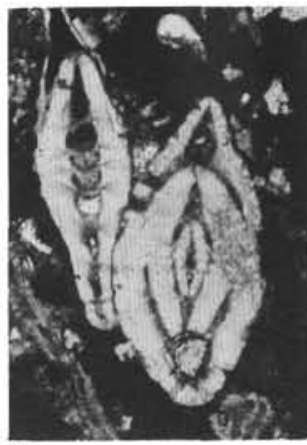

15

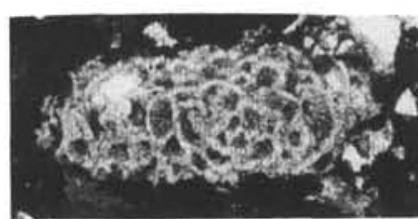

16

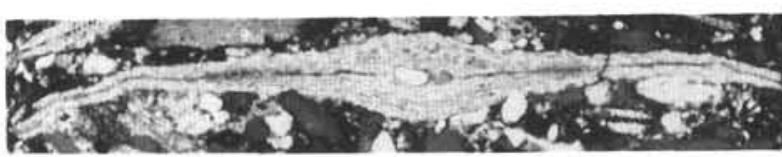

Plate 3. 1. Globigerinatheka sp., Sample $135-841 \mathrm{~B}-46 \mathrm{R}-1,35-39 \mathrm{~cm}$; CPC $30829, \times 50$. 2. Globigerinatheka sp., Sample 135-841B-47R-2, 92-96 cm; CPC $30830, \times 65$. 3. Morozovella sp., vertical section. Sample 135-841B-47R-2,92-96 cm; CPC30831, ×60. 4-5. Sherbornina carteri, vertical sections. Samples 135-841B-46R-CC, and $-47 \mathrm{R}-2,92-96 \mathrm{~cm}$; CPC30832 and CPC30833, $\times 60$ and $\times 75$, respectively. 6-7. Amphistegina waiareka, oblique vertical sections, Samples 135-841B-46R-1, 35-39 cm, and, $-47 \mathrm{R}-2,92-96 \mathrm{~cm}$; CPC 30834 and CPC30835, $\times 40$ and $\times 50$, respectively. 8. Halkyardia ?minima, vertical section, Sample 135-841B-47R-1, 92-96 cm; CPC30836, $\times 70$. 9. Asterigerina tentoria, vertical section, Sample 135-841B-46R-2, 140-143 cm; CPC30837, $\times 55$. 10. Operculina pacifica, vertical section. Sample 135-841B-46R-1, 35-39 cm; CPC 30838, $\times 20$. 11. Heterostegina saipanensis, vertical section. Sample 135-841B-46R-CC; CPC30839, $\times 25$. 12-13. Spiroclypeus vermicularis, vertical section, Samples $135-841 \mathrm{~B}-46 \mathrm{R}-3,10-13 \mathrm{~cm}$, and $-46 \mathrm{R}-\mathrm{CC}$, CPC 30840 and CPC30841, $\times 20$ and $\times 30$, respectively. 14. Nummulites pengaronensis, vertical section, Sample 135-841B-46R-1, 88-91 cm; CPC30842, $\times 35$. 15. ?Heterostegina saipanensis and Nummulites pengaronensis, vertical sections, Sample 135-841B-46R-CC; CPC30843 and CPC $30844, \times 30$. 16. Discogypsina discus, vertical section, Sample 135-841B-46R-CC; CPC30845, ×45. 17. Halimeda sp., transverse section, Sample 135-841B-46R-CC; CPC30846, ×20. 18. Discocyclina omphala, centered vertical section, Sample 135-841B-46R-CC; CPC30847, ×20. 


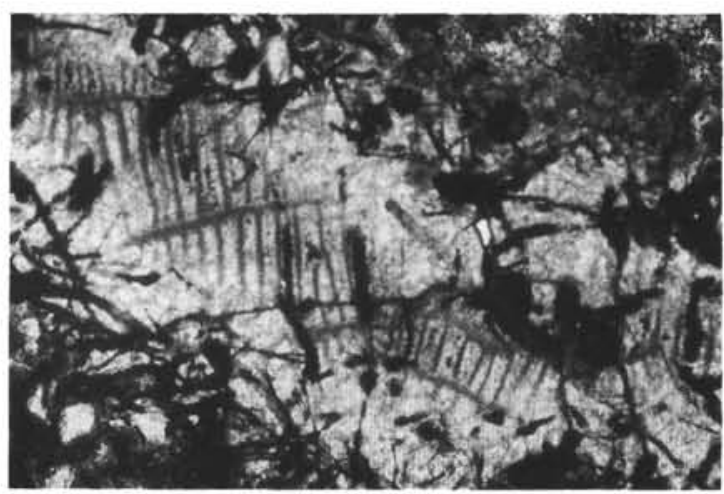

1

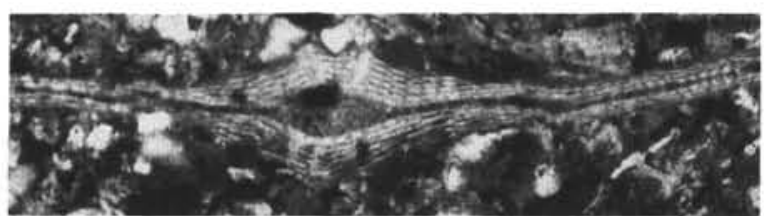

2

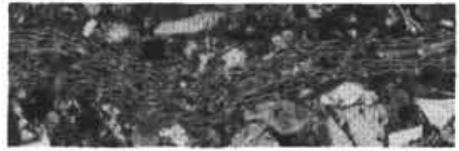

3
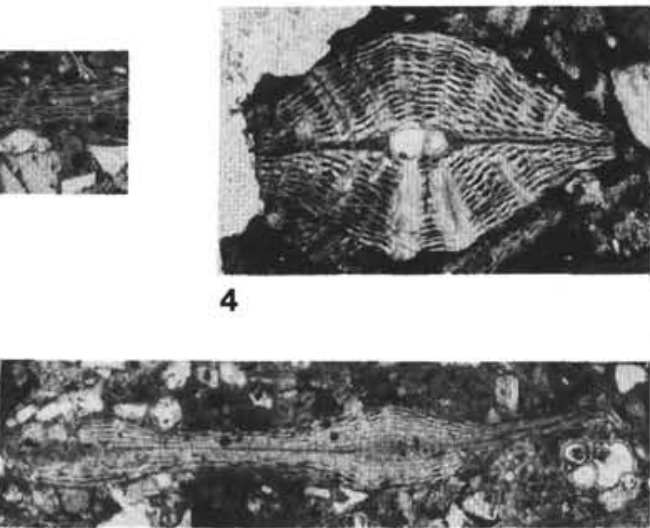

7

6

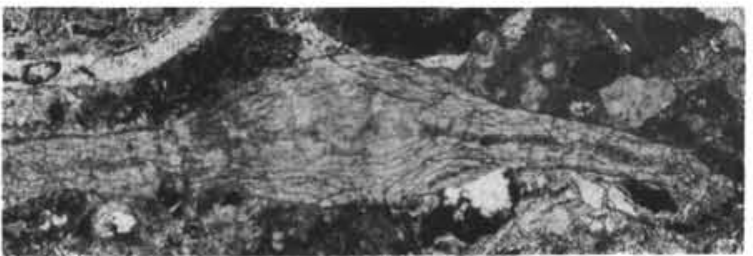

8
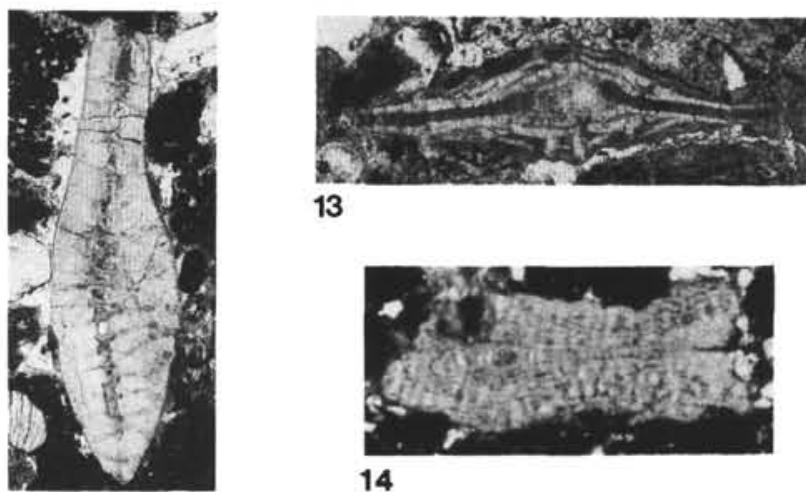

13

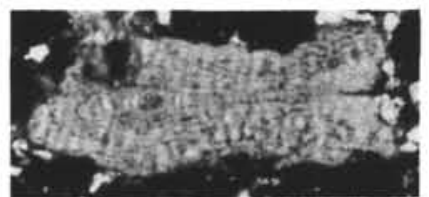

14

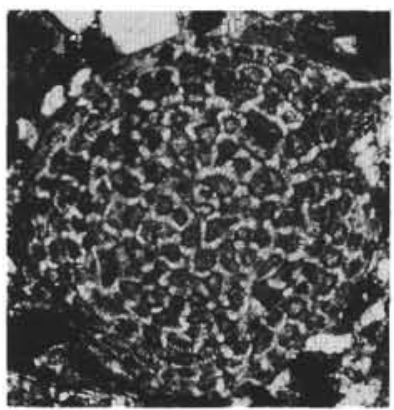

9

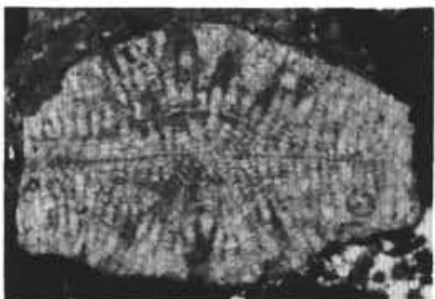

15

Plate 4. 1. Discocyclina omphala, detail of equatorial chambers, Sample $135-841 \mathrm{~B}-46 \mathrm{R}-1,88-91 \mathrm{~cm} ; \mathrm{CPC} 30848, \times 50$. 2. Discocyclina omphala, near-centered vertical section, Sample 135-841B-46R-2, 140-143 cm; CPC30849, $\times 40$. 3. Discocyclina omphala, detail of vertical section showing distortion of test without being fractured, Sample 135-841B-46R-2, 62-65 cm; CPC30850, $\times 20$. 4. Discocyclina omphala, centered vertical section, Sample 135-841B-46R-CC; CPC 30851, $\times 15$. 5. Discocyclina omphala, detail of equatorial chambers, Sample 135-841B-46R-2, 140-143 cm; CPC30852, $\times 15$. 6. Asterocyclina matanzensis, vertical section, Sample 135-84IB-46R-3, 10-13 cm; CPC30853, $\times 40$. 7. Asterocyclina matanzensis, vertical section, Sample 135-841B-46R-2, 62-65 $\mathrm{cm} ; \mathrm{CPC} 30854, \times 30$. 8. Cycloclypeus sp., vertical section, Sample $135-841 \mathrm{~B}-41 \mathrm{R}-2,110-114 \mathrm{~cm} ; \mathrm{CPC} 30855, \times 15$. 9. Sphaerogypsina globula, oblique vertical section, Sample 135-841B-41R-2, 110-114 cm; CPC30856, ×30. 10. Amphistegina radiata, vertical section, Sample 135-841B-41R-2, 110-114 cm; CPC30857, $\times 30$. 11. Amphistegina ?waiareka, centered vertical section, Sample $135-841 \mathrm{~B}-22 \mathrm{R}-3,10-14 \mathrm{~cm} ; \mathrm{CPC} 30858, \times 25$. 12. Heterostegina saipanensis, oblique vertical section, Sample 135-841B-22R-3, 10-14 cm; CPC30859, $\times 20$. 13. Lepidocyclina (Nephrolepidina) ?howchini, centered vertical section, Sample 135-841B-41R-2, 110-114 cm; CPC30860, $\times 30$. 14. Asterocyclina matanzensis, oblique vertical section, Sample 135-841B-21R-2, 131-135 cm; CPC30861, $\times 30$. 15. Discocyclina omphala, vertical section, Sample $135-841 \mathrm{~B}-22 \mathrm{R}-1,5-8 \mathrm{~cm} ; \mathrm{CPC} 30862, \times 30$. 


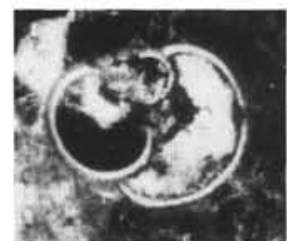

1

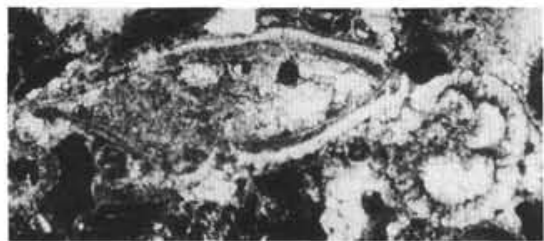

2

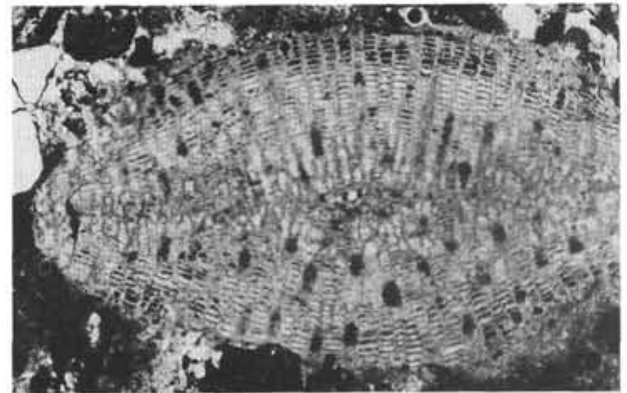

3

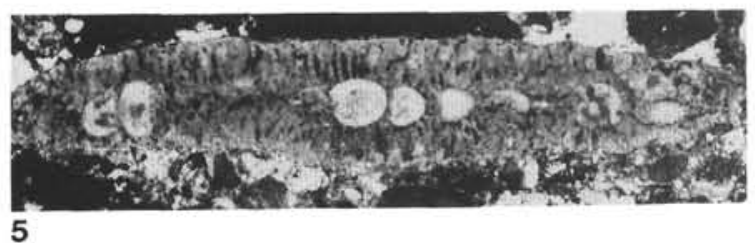

Plate 5. 1. Pulleniatina sp., near-centered vertical section, Sample $135-841 \mathrm{~B}-20 \mathrm{R}-3,66-69 \mathrm{~cm} ; \mathrm{CPC} 30863, \times 70$. 2. Globorotalia (Globorotalia) tumida ?plesiotumida, oblique vertical section, Sample 135-841B-20R-3, 66-69 cm; CPC30864, $\times 70$. 3. Discocyclina omphala, vertical section, Sample 135-841B20R-2, 111-115 cm; CPC30865, $\times 20$. 4. Pellatispira madaraszi, vertical section, Sample 135-841B-20R-2, 111-115 cm; CPC30866, $\times 2.5$. 5. Pellatispira madaraszi, vertical section, Sample 135-841B-20R-2, 111-115 cm; CPC30867, ×20. 